Research Paper

\title{
Clinical efficacy of omalizumab in chronic spontaneous urticaria is associated with a reduction of FceRI-positive cells in the skin
}

\author{
Martin Metz ${ }^{1}$, Petra Staubach², Andrea Bauer ${ }^{3}$, Randolf Brehler ${ }^{4}$, Janine Gericke ${ }^{1 *}$, Michael Kangas ${ }^{5}$, Joanna \\ Ashton-Chess 5 , Philip Jarvis ${ }^{5}$, Panayiotis Georgiou ${ }^{5 \dagger}$, Janice Canvin ${ }^{5}$, Rainer Hillenbrand ${ }^{5}$, Veit J. \\ Erpenbeck 5 , Marcus Maurer ${ }^{1 凶}$ \\ 1. Department of Dermatology and Allergy, Charité - Universitätsmedizin, Berlin, Germany; \\ 2. Department of Dermatology, University Medicine Mainz, Germany; \\ 3. Department of Dermatology, University Allergy Center, University Hospital Carl Gustav Carus, Technical University Dresden, Germany; \\ 4. Department of Dermatology, University Hospital Muenster, Germany; \\ 5. Translational Medicine, Novartis Pharma AG, Basel, Switzerland \\ * Current address: Novartis Pharma AG, Basel, Switzerland \\ † Current address: Clovis Oncology, Cambridge UK. \\ $\square$ Corresponding author: Marcus Maurer, MD, Professor of Dermatology and Allergy, Director of Research, Dpt. of Dermatology and Allergy, \\ Allergie-Centrum-Charité, Charité - Universitätsmedizin Berlin, Charitéplatz 1 * 10117 Berlin * Germany. Tel +49 30450518043 ; Email: \\ Marcus.Maurer@charite.de \\ (C) Ivyspring International Publisher. This is an open access article distributed under the terms of the Creative Commons Attribution (CC BY-NC) license \\ (https://creativecommons.org/licenses/by-nc/4.0/). See http://ivyspring.com/terms for full terms and conditions.
}

Received: 2016.11.11; Accepted: 2017.01.16; Published: 2017.03.06

\begin{abstract}
Background. Treatment with omalizumab, a humanized recombinant monoclonal anti-lgE antibody, results in clinical efficacy in patients with Chronic Spontaneous Urticaria (CSU). The mechanism of action of omalizumab in CSU has not been elucidated in detail.

Objectives. To determine the effects of omalizumab on levels of high affinity lgE receptor-positive (FcعRI+) and lgE-positive $\left(\mathrm{lgE}^{+}\right)$dermal cells and blood basophils. Treatment efficacy and safety were also assessed.

Study design. In a double-blind study, CSU patients aged 18-75 years were randomized to receive $300 \mathrm{mg}$ omalizumab $(n=20)$ or placebo $(n=10)$ subcutaneously every 4 weeks for 12 weeks. Changes in disease activity were assessed by use of the weekly Urticaria Activity Score (UAS7). Circulating IgE levels, basophil numbers and levels of expression of $\mathrm{FcERI}^{+}$and $\mathrm{IgE}{ }^{+}$cells in the skin and in blood basophils were determined.

Results. Patients receiving omalizumab showed a significantly greater decrease in UAS7 compared with patients receiving placebo. At Week 12 the mean difference in UAS7 between treatment groups was -14.82 $(p=0.0027)$, consistent with previous studies.

Total lgE levels in serum were increased after omalizumab treatment and remained elevated up to Week 12. Free IgE levels decreased after omalizumab treatment.

Mean levels of $\mathrm{FcERI}^{+}$skin cells in patients treated with omalizumab $300 \mathrm{mg}$ were decreased at Week 12 compared with baseline in the dermis of both non-lesional and lesional skin, reaching levels comparable with those seen in healthy volunteers $(\mathrm{HVs})$. There were no statistically significant changes in mean $\mathrm{FcERI}^{+}$cell levels in the placebo group. Similar results were seen for changes in lgE $\mathrm{E}^{+}$cells, although the changes were not statistically significant.

The level of peripheral blood basophils increased immediately after treatment start and returned to Baseline values after the follow-up period. The levels of $F \subset \varepsilon R I$ and IgE expression on peripheral blood basophils were rapidly reduced by omalizumab treatment up to Week 12 .

Conclusions. Treatment with omalizumab resulted in rapid clinical benefits in patients with CSU. Treatment with omalizumab was associated with reduction in $\mathrm{FcE} \mathrm{RI}^{+}$and $\mathrm{lgE} \mathrm{E}^{+}$basophils and intradermal cells.
\end{abstract}

Key words: Omalizumab, Chronic Spontaneous urticaria, mode of action 


\section{Introduction}

Omalizumab $\left(\right.$ Xolair $\left.^{\circledR}\right)$ is a recombinant humanized monoclonal antibody that binds to IgE at its binding site to the high-affinity IgE receptor (FccRI) [1]. Free IgE levels fall between 89 to $98 \%$ over 16 to 24 weeks of therapy. Associated with the decrease in free IgE levels is a down-regulation in the expression of FceRI receptors on basophils and mast cells [2-4]. In addition, recent data show that omalizumab is able to dissociate pre-bound $\mathrm{IgE}$ from mast cells and basophils $[5,6]$.

Omalizumab is effective in the treatment of chronic spontaneous / idiopathic urticaria (CSU / CIU) [7-13] including in patients who have relapsed after stopping treatment with omalizumab [14]. Omalizumab is approved for the treatment of CSU (in the EU) and CIU (in the USA) patients who remain symptomatic despite H1-antihistamine treatment [15, 16].

Urticaria is characterized by the development of hives, angioedema, or both [17]. Pathogenesis of CSU is not fully understood [17]. It appears to be a mast cell- and basophil-mediated hypersensitivity reaction [18-22]. Histamine and other mediators are released on activation of basophils and mast cells, and these mediators ultimately give rise to the clinical signs and symptoms of CSU. The pathology of CSU lesions resembles that of allergen-mediated late-phase skin reactions, suggesting involvement of FceRI activation of mast cells and basophils [23]. Antigen cross-linking of $\operatorname{IgE}$ bound to FceRI is a known mediator of basophil and mast cell activation [24]. Also, approximately 45\% of CSU patients have histamine-releasing autoantibodies against either FceRI or IgE $[25,26]$; the clinical significance is unclear, but as cross-linking of IgE or FceRI on mast cell or basophil surface may result in activation and release of inflammatory mediators [27-29], these antibodies may be involved in disease pathogenesis [30, 31]. It has also been suggested that basophils in CSU patients may have distinct alterations in FceRIa mediated degranulation, independent of any role of autoantibodies [32-34].

Little is known about the effects of omalizumab on basophil numbers and function in CSU. A previous skin biopsy study in patients with allergic rhinitis [4] showed that omalizumab treatment was associated with a decrease in the number of $\mathrm{FcERI}^{+}$mast cells in the skin and basophils in the blood, and that this was associated with a reduction in the size of allergen-induced hives in intradermal skin tests. Treatment with omalizumab reduced serum IgE and $\mathrm{IgE}^{+}$cells in the airway mucosa of patients with allergic asthma [35]. The effects of omalizumab on basophils from the circulation of CSU patients has been described before [36] but little is known about local effects of omalizumab treatment in the skin. Therefore, the current study took biopsies from lesional and non-lesional skin of CSU patients, to evaluate the effects of treatment with omalizumab on basophil numbers and levels of $\mathrm{FcERI}^{+}$and $\mathrm{IgE}^{+}$skin cells in CSU patients compared with that of skin from healthy volunteers.

\section{Methods}

This was an exploratory, double-blind, parallel group, randomized, placebo-controlled Phase II study (NCT01599637, EudraCT no. 2011-004216-31; Figure 1). Patients were enrolled at 4 centers in Germany. The study was conducted in accordance with applicable local regulations (including European Directive 2001/20/EC, US Code of Federal Regulations Title 21, and Japanese Ministry of Health, Labor, and Welfare), the International Conference on Harmonization E6 Guideline for Good Clinical Practice, and the ethical principles of the Declaration of Helsinki. The study protocol and all amendments were reviewed by the Independent Ethics Committee (IEC) or Institutional Review Board (IRB) for each center and written informed consent was obtained from study participants before enrollment.

\section{Study design}

For CSU patients, the study consisted of a 10-day screening period, during which patient eligibility for study entry was assessed, followed by a 3-day washout period and a 14-day baseline period (Figure 1). During this period, urticaria activity was assessed. In patients who had taken rescue medication due to high disease activity (a short-acting, non-sedating antihistamine), the following day was not counted in order to exclude any carry-over effect. However, if the urticaria activity score (UAS) for that day was 6, the day was counted irrespective of medication use on the previous day. For the calculation of the baseline UAS7 seven individual days were calculated counting backwards, beginning with the last day before randomization. The treatment period was 12 weeks; on Day 1 of the treatment period, patients were randomized in a 2:1 ratio to omalizumab $300 \mathrm{mg}$ or placebo (3 subcutaneous doses at 4-weekly intervals, i.e. at Day 1, Week 4 and Week 8). After stopping the treatment, patients were followed for an additional 8 weeks (follow-up). The total duration of the study per patient was approximately 23 weeks. Skin biopsies were taken from CSU patients at baseline, Week 1 , 
Week 4 (optional), Week 12, and Week 20 (after follow-up) from non-lesional and lesional skin (as available). The optional biopsy at Week 4 was taken from patients who showed response to treatment at that time-point (defined as UAS7 $\leq 6$ ), while no response (UAS7 $\geq 16$ ) was seen at Week 1 . On dosing days (Day 1 and Day 29), biopsies were taken pre-dose and blood samples were taken for measurement of basophils. The eligibility of the healthy volunteers (HVs) was assessed at a screening visit, then at Day 1 a single skin biopsy was collected and study completion assessments performed.

\section{Study population}

The study included patients, aged 18 to 75 years, diagnosed with CSU who remained symptomatic despite H1-antihistamine treatment at approved doses, defined as presence of itch and hives for over 6 weeks prior to baseline, with UAS7 score of at least 16 and itch component of UAS7 of at least 8 during the 14 days prior to randomization. Patients had to have had a CSU diagnosis for at least 6 months, and be on an approved dose of an H1-antihistamine for CSU prior to entering the study.

Exclusion criteria included weight $>130 \mathrm{~kg}$ or $<40 \mathrm{~kg}$ at screening; heavy smoking; chronic urticaria other than CSU; diseases with symptoms of urticaria or angioedema (e.g. urticarial vasculitis, urticaria pigmentosa, erythema multiforme, mastocytosis, hereditary or acquired angioedema, lymphoma, leukemia, or generalized cancer); history or presence of atopic dermatitis, bullous pemphigoid, dermatitis herpetiformis, senile pruritus or other skin disease associated with itch; evidence of parasitic infection; any clinically relevant major systemic disease that could potentially complicate interpretation of study results; and inability to comply with study and follow-up procedures. All subjects (both CSU patients and controls) with asthma and atopic dermatitis were excluded. History of clinically significant hypersensitivity to omalizumab or similar drugs, or to local anesthetics, and history of anaphylactic shock were also exclusion criteria.

Patients were not allowed to be using other investigational drugs at the time of randomization (Day 1), or within 30 days or 5 half-lives of enrollment, whichever was longer; could not have had previous treatment with omalizumab; could not be receiving routine doses of systemic or topical corticosteroids, hydroxychloroquine, methotrexate, cyclosporine, cyclophosphamide or any other immunomodulating drug (e.g. interferons) that could alter the response to omalizumab treatment, or IV immunoglobulin $\mathrm{G}$, or plasmapheresis within 30 days prior to -2 weeks. Regular oral doxepin use within 6 weeks prior to -2 weeks, use of any $\mathrm{H} 2$ antihistamine or any leukotriene receptor antagonists (LTRAs) within 7 days prior to -2 weeks, or use of any H1 antihistamines at greater than approved doses within 3 days prior to -2 weeks were also not permitted. Patients needed to be on stable doses for 4 weeks prior to randomization (Day 1). Loratadine (a short-acting, non-sedating antihistamine), was allowed to be used as a rescue medication on an as needed basis up to 4 times the recommended dose of $10 \mathrm{mg}$, for angioedema or other reasons specified by the patient. The use of loratadine was documented by the patient in a diary.

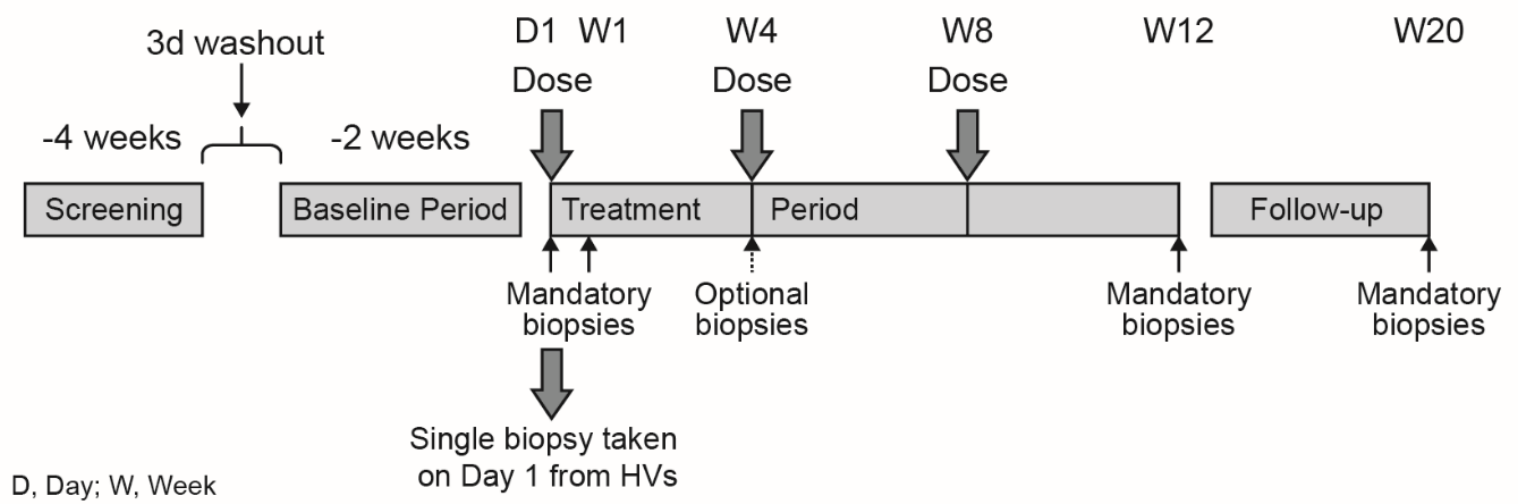

Optional biopsy at Week 4 for patients who showed response to treatment at that time point while no response was seen at Week 1. Response was defined as UAS7 $\leq 6$, Non-response was UAS7 $\geq 16$. On dosing days (Day 1 and Week 4 ), biopsies were taken pre-dose.

CSU patients who were experiencing symptoms and whose skin was macroscopically affected had lesional skin, while those that were not had non-lesional skin.

Figure 1. Study design. 
Age and gender-matched healthy volunteers participated in the study to the CSU patients, and were in good health. Exclusion criteria for healthy volunteers were similar to those for CSU patients (except for those criteria specifically related to urticaria and its treatment), with the addition of the use of any prescription drug or over-the-counter medication within 2 weeks prior to Day 1 (paracetamol was acceptable, but its use had to be documented).

\section{Study endpoints}

The primary variable was the relative change from baseline to Week 12 in the $\mathrm{FccRI}^{+}$and/or $\mathrm{IgE}^{+}$ skin cells, based on skin biopsies collected from CSU patients. Skin biopsy data from healthy volunteers were used as a reference for data from CSU patients.

\section{Assessments}

Clinical efficacy and quality of life were assessed using UAS7, patient's and investigator's global assessment of symptoms using a graded Likert scale scoring of symptoms (urticaria lesions [hives] and itch), angioedema, Dermatology Life Quality Index (DLQI), Skindex-29, and Chronic Urticaria Quality of Life Questionnaire (CU-Q $\left.{ }_{2} \mathrm{OL}\right)$ [37].

Patient symptoms of itch and hives were recorded via electronic diary (eDiary) each morning and evening on a daily basis to assess UAS. The composite eDiary-recorded score with numeric severity intensity ratings on a scale of $0-3(0=$ none to $3=$ intense/severe) for the number of hives and the intensity of itch. Daily UAS was calculated as the average of the morning and evening scores; UAS7 is the sum of the daily UAS scores over 7 days. Response to treatment was defined as a $90 \%$ reduction from baseline in UAS7, a cut-off previously used to illustrate complete response in a retreatment study [14].

Safety was assessed in terms of the frequency and severity of adverse events (AEs), vital signs, ECG evaluations, and clinical laboratory measurements. Serum omalizumab concentrations were evaluated using a validated ELISA method with an anticipated Lower Limit of Quantification (LLOQ) of $28 \mathrm{ng} / \mathrm{mL}$.

\section{Measurement of basophils}

Blood samples were taken and incubated with antibodies (Lineage cocktail-FITC [Becton Dickinson], CD203c/PerCPCy5.5 [Biolegend], IgE-PE [Biolegend] and FceR1-APC [eBioscience]) at RT, fixed with 1\% paraformaldehyde in phosphate buffered saline (PBS) and the samples stored frozen at $-80^{\circ} \mathrm{C}$ before shipment on dry ice to a central processing laboratory. Thawed samples were processed as follows: after centrifugation for $7 \mathrm{~min}$ at $500 \mathrm{~g}$ at RT, the pellets were washed and aspirated twice, before being resuspended in $200 \mu 1 \%$ paraformaldehyde in PBS. They were then analyzed within 4 hours by fluorescent antibody cell sorting (FACS) performed on a FACS-Canto II (Becton Dickinson, CA, USA) using the FACSDiva software after adjustment with antibodies bound to compensation particles. Mean values and the coefficient of variation $(\mathrm{CV})$ were calculated and a CV $<30 \%$ was acceptable.

\section{Analysis of IgE}

Blood samples were collected into additive free tubes and allowed to clot over a minimum of $30 \mathrm{~min}$ at room temperature (RT). Serum was collected after centrifugation at approximately $3500 \mathrm{rpm}$ for $10 \mathrm{~min}$. Serum samples were split into 2 aliquots and stored at $-20^{\circ} \mathrm{C}$ until analysis at the central laboratory. Serum levels of free $\operatorname{IgE}$ and total $\operatorname{IgE}$ (i.e. the sum of free and bound IgE) were determined by specific immunoassays, as described previously [38].

\section{Biopsies}

Patients provided biopsies from non-lesional and lesional skin (as available). An optional biopsy could be performed at Week 4; this was targeted at slower responding patients and therefore the numbers of biopsies collected at this time-point depended on response to treatment. Skin biopsies with a minimum diameter of $6 \mathrm{~mm}$ were taken at each scheduled time-point. Baseline biopsies were taken from one location with lesional skin and from one with non-lesional skin. Following treatment, biopsies were taken at locations close to the locations chosen at baseline. Biopsy samples were stored at $-80^{\circ} \mathrm{C}$ until sectioned.

\section{Histopathology procedures}

Biopsy samples were examined using immunohistochemistry techniques. Samples from skin biopsies were sectioned $(5 \mu \mathrm{m})$ with a cryostat at approximately $-21^{\circ} \mathrm{C}$ and placed on glass slides. After fixing with acetone $\left(-20^{\circ} \mathrm{C}\right.$ for $\left.10 \mathrm{~min}\right)$, sections were dried and kept at $-20^{\circ} \mathrm{C}$. Staining (IHC, Giemsa, or $H \& E$ ) was carried out on thawed samples.

Immunohistochemical staining with alkaline phosphatase (AP) was performed to analyze FceRI and IgE. Samples were thawed and blocked sequentially with biotin and avidin for 15 mins at RT, followed by $2 \%$ fetal calf serum (FCS) in Tris-buffered saline (TBS) for 20 mins at RT. Samples were then incubated with specific primary antibodies, diluted in TBS + 1\% FCS for 1 hour at RT: mouse anti-CD117 (BD 555713), diluted 1:400; mouse anti-CD11c (BD 550375) diluted 1:400; mouse anti-CD8 (DakoM7103) diluted 1:150; mouse anti CD4 (Dako M7310) diluted 1:200; mouse anti-CD3 (Dako (M7254) diluted 1:400; mouse 
anti FCعR1 (eBioscience 14-5899) diluted 1:400; mouse anti-tryptase (Dako M7052) diluted 1:500; or rabbit anti-IgE (Dako A0094) diluted 1:5000. Negative control staining was carried out using the same concentration of IgG1 (Dako X0931), IgG2bk (eBioscience 14-4732) or rabbit IgG (Dako X0936).

Samples were then incubated with a biotinylated secondary antibody (Link Antibody ready to use, Dako REAL Detection System K50050) for 15 mins at RT, then with streptavidin-alkaline phosphatase (Dako REAL Detection System K5005) for 15 mins at RT, then with levamisole for 15 mins at RT before being counterstained with hematoxylin for 5 seconds at RT and mounted in aqueous solution.

Hematoxylin and eosin staining was carried out on cryosections using Papanicolaous Solution 1a Harris' hematoxylin solution (Merck \# 1.09253.2500) and Eosin-Phloxin Solution (Hollborn, 1 L, \# 601017). Samples were mounted in Clarion environmentally safe permanent mounting media.

Alkaline Giemsa-Staining was carried out on cryosections using Giemsa Azur Eosin-Methylenblau $1: 10$ with $2 \%$ sodium borate solution before mounting with Clarion environmentally safe permanent mounting media.

Skin biopsy samples were scored on an average number of positive cells from 5 visual fields.

\section{Data analyses}

Analyses of cellular data were based on the pharmacodynamic (PD) analysis population, which included all subjects who received at least one dose of study drug and had evaluable PD data. The primary variable was the relative change from baseline in $\mathrm{FcERI}^{+}$and/or IgE ${ }^{+}$skin cells, based on skin biopsies collected from patients with CSU after 12 weeks of treatment relative to placebo. A two-tailed two-sample t-test was used to compare groups that employed a 5\% significance level.

Correlation between UAS7 and the FceRI- and IgE-positive skin cells for baseline values and for the change from baseline to Day 85 was assessed using Spearman's and Pearson's correlation analysis. All results are given as two-tailed $p$-values, and $p<0.05$ was considered statistically significant.

All efficacy analyses were performed on the intent-to-treat (ITT) population which included all randomized patients who received at least one dose of study drug and had post-randomization efficacy data. The treatment groups were based on the treatment assigned at randomization. For efficacy endpoints, descriptive statistics were provided by treatment group and time-point. UAS7 was also modeled using a repeated measures ANCOVA model with baseline UAS7 score as a covariate, and treatment, time, and treatment by time interaction as fixed factors.

All subjects who received at least one dose of study drug were included in the safety analysis.

\section{Results}

\section{Disposition of participants}

Thirty patients were randomized to treatment, 20 in the omalizumab group and 10 in the placebo group (Figure 2). One patient receiving omalizumab discontinued prematurely (due to an AE), as did two patients in the placebo group (due to administrative problems). Data were analyzed from 17 omalizumab-treated patients and 9 patients in the placebo group. All 10 healthy volunteers who entered the study completed their single study visit.

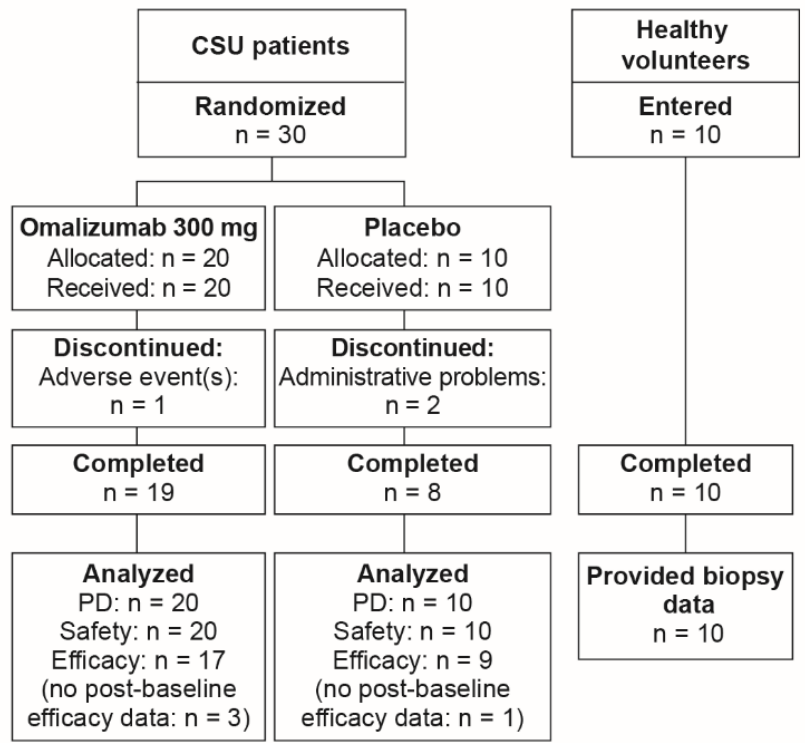

Figure 2. Participant flow.

\section{Participant demographics and baseline characteristics}

The omalizumab and placebo groups of CSU patients were generally well matched for demographic characteristics. All patients were Caucasian and $87 \%$ were female. The mean age was 38.7 years, with a range of 23 to 63 years. The mean BMI was $27.7 \mathrm{~kg} / \mathrm{m}^{2}$. There were four subjects with reported allergies in the omalizumab-treated group and one subject in the placebo-treated group.

Of the 10 healthy control subjects, all were Caucasian and female, with a mean age of 36.4 years (range 24 to 51 years) and mean BMI of $24.2 \mathrm{~kg} / \mathrm{m}^{2}$.

UAS7 scores at baseline were comparable between the groups. Mean (SD) baseline serum total IgE concentrations were 1037 (2474) $\mathrm{ng} / \mathrm{mL}$ in the omalizumab $300 \mathrm{mg}$ group and $442(581) \mathrm{ng} / \mathrm{mL}$ in the placebo group (Table 1). 


\section{Omalizumab reduces CSU activity}

Decreases in UAS7 after omalizumab treatment initiation were rapid (with separation of the curves at Day 3) and sustained (Figure 3). At Week 12, the LS mean difference in UAS7 between treatment groups was $-14.82(p=0.0027)$.

More than $50 \%$ of patients in the omalizumab group were UAS7 responders at Week 12 (Figure 4). About half of these had become responders by the end of Week 2. In contrast, $<15 \%$ of patients receiving placebo had improved by Week 12, without any change occurring by Week 2 .

The DLQI overall score, Skindex-29 score and $\mathrm{CU}-\mathrm{Q}_{2} \mathrm{OL}$ overall score all showed larger decreases from baseline in the omalizumab group than the placebo group. Mean (SD) scores at Week 12 are shown in Table 2. In addition, physicians' and patients' global assessment scores, itch, hives scores as well as loratadine use showed statistically significant differences between omalizumab and placebo-treated patients at Week 12 (Table 2).

Table 1. Demographic summary.

\begin{tabular}{llll}
\hline & $\begin{array}{l}\text { Omalizumab } \\
300 \mathrm{mg}\end{array}$ & Placebo & $\begin{array}{l}\text { Healthy } \\
\text { volunteers }\end{array}$ \\
\hline & $\mathrm{N}=20$ & $\mathrm{~N}=10$ & $\mathrm{~N}=10$ \\
Age (years) & $37.5(11.0)$ & $41.1(8.0)$ & $36.4(9.7)$ \\
Height (cm) & $171.4(7.3)$ & $172.1(10.8)$ & $166.4(6.3)$ \\
Weight $(\mathrm{kg})$ & $78.5(16.0)$ & $87.4(21.6)$ & $66.9(13.4)$ \\
Female - n (\%) & $18(90)$ & $8(80)$ & $10(100)$ \\
Race Caucasian - $\mathrm{n}$ & $20(100)$ & $10(100)$ & $10(100)$ \\
$(\%)$ & & & \\
BMI $\left(\mathrm{kg} / \mathrm{m}^{2}\right)$ & $26.8(5.8)$ & $29.3(5.6)$ & $24.2(5.3)$ \\
Baseline IgE (ng/ml) & $1037(2474)$ & $442(581)$ & $\mathrm{N} / \mathrm{A}$ \\
Baseline UAS7 & $32.2(8.0)$ & $31.6(7.7)$ & $\mathrm{N} / \mathrm{A}$ \\
\hline
\end{tabular}

Data are provided as mean (Standard deviation) unless otherwise indicated Age was calculated from date of screening and date of birth

Weight and height were taken from screening vital signs evaluations

BMI, Body Mass Index , UAS, Urticaria Activity Score, UAS7, the sum of the daily UAS scores over 7 days, IgE, Immunoglobulin E
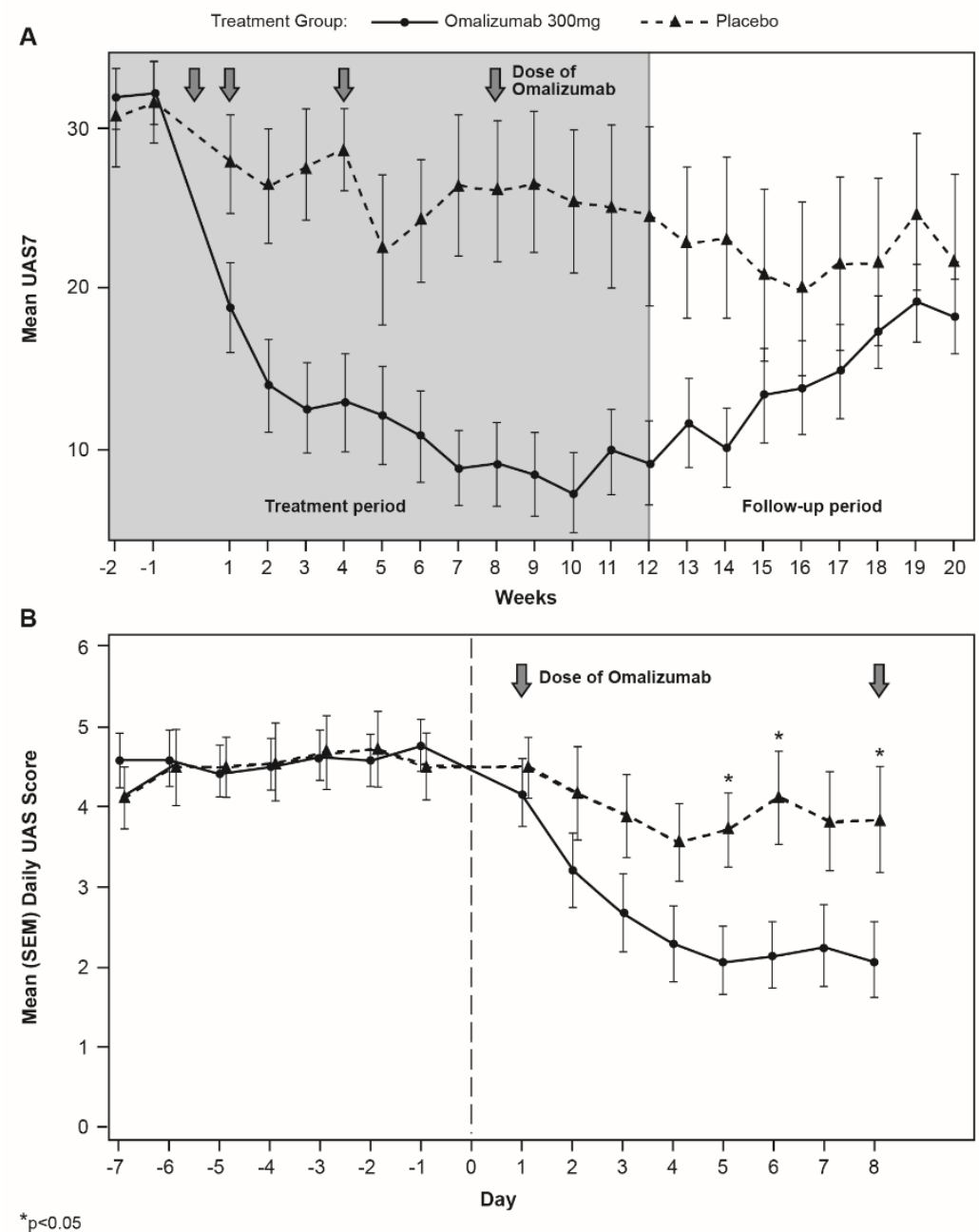

Figure 3. Longitudinal UAS7 modulation by treatment. Mean (SEM) UAS7 by treatment and week over the treatment and follow-up period (A) or by UAS per day during the first week of the treatment period (B). 


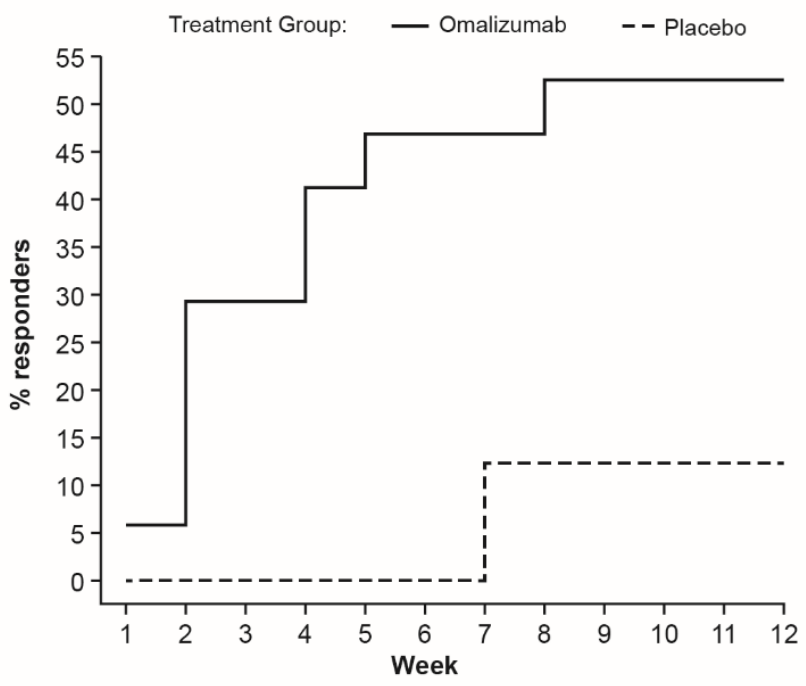

Figure 4. Responders to treatment. Proportion of patients with a defined first occurrence of UAS7 response, defined as a greater than $90 \%$ reduction from baseline in UAS7 score (UAS7 is the sum of the daily UAS scores over 7 consecutive days).

\section{Omalizumab increases total serum IgE levels}

Total serum IgE levels are known to increase 3to 5-fold after omalizumab administration due to formation of IgE-anti-IgE complexes and altered rates of clearance. In this study, total IgE serum levels increased after the first treatment and remained elevated up to Week 12 . The increase largely occurred by Day 8 . No change was observed in placebo-treated subjects and in these subjects total $\operatorname{IgE}$ equals free $\operatorname{IgE}$ (Figure 5A).

In omalizumab-treated subjects, the free $\operatorname{IgE}$ levels decreased after the first treatment and remained suppressed until Week 12 (Figure 5B). Virtually all of the decrease occurred during the first 48 hours following treatment.

Table 2. Clinical efficacy data at Week 12.

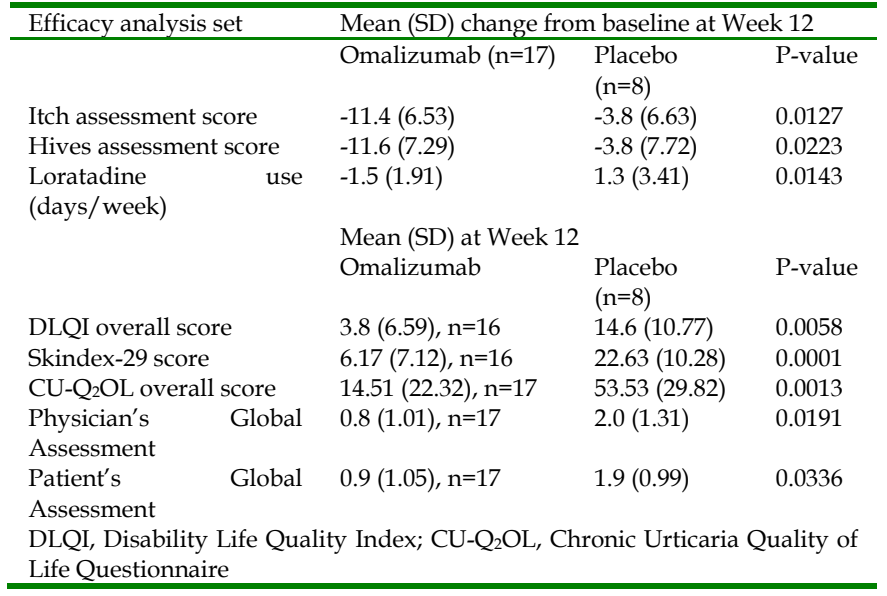
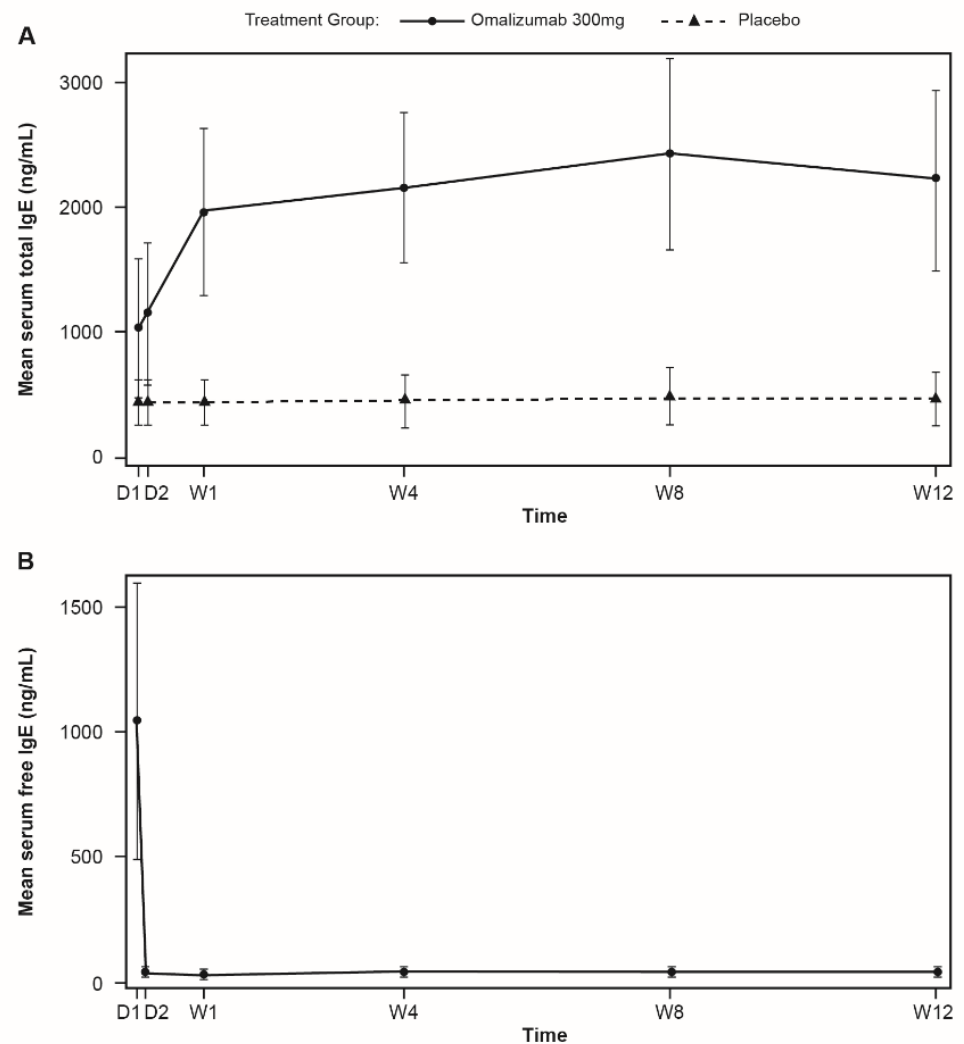

D, Day; W, Week

Figure 5. Total $\lg E(\mathbf{A})$ and Free $\lg E(\mathbf{B})$ serum levels shown as mean (SEM). For serum free $\lg E$ at Day 1 (baseline), total lgE data was used. D, day; W, week 


\section{Omalizumab increases peripheral blood basophils and reduces basophil FceRI and IgE expression}

Mean levels of basophils are low in untreated CSU patients. In patients treated with omalizumab there was a non-statistically significant increase in peripheral blood basophils over the treatment period compared with placebo, mostly occurring by Week 2 , but basophil levels returned to patients' baseline values after the follow-up period (Figure 6A).

Omalizumab treatment reduced FceRI and $\operatorname{IgE}$ expression on peripheral blood basophils early in the treatment period (by Week 1 ) and the reduction was sustained through to Week 12 (Figure 6B and C). These values started to return towards baseline, but did not reach baseline values during the follow-up period.
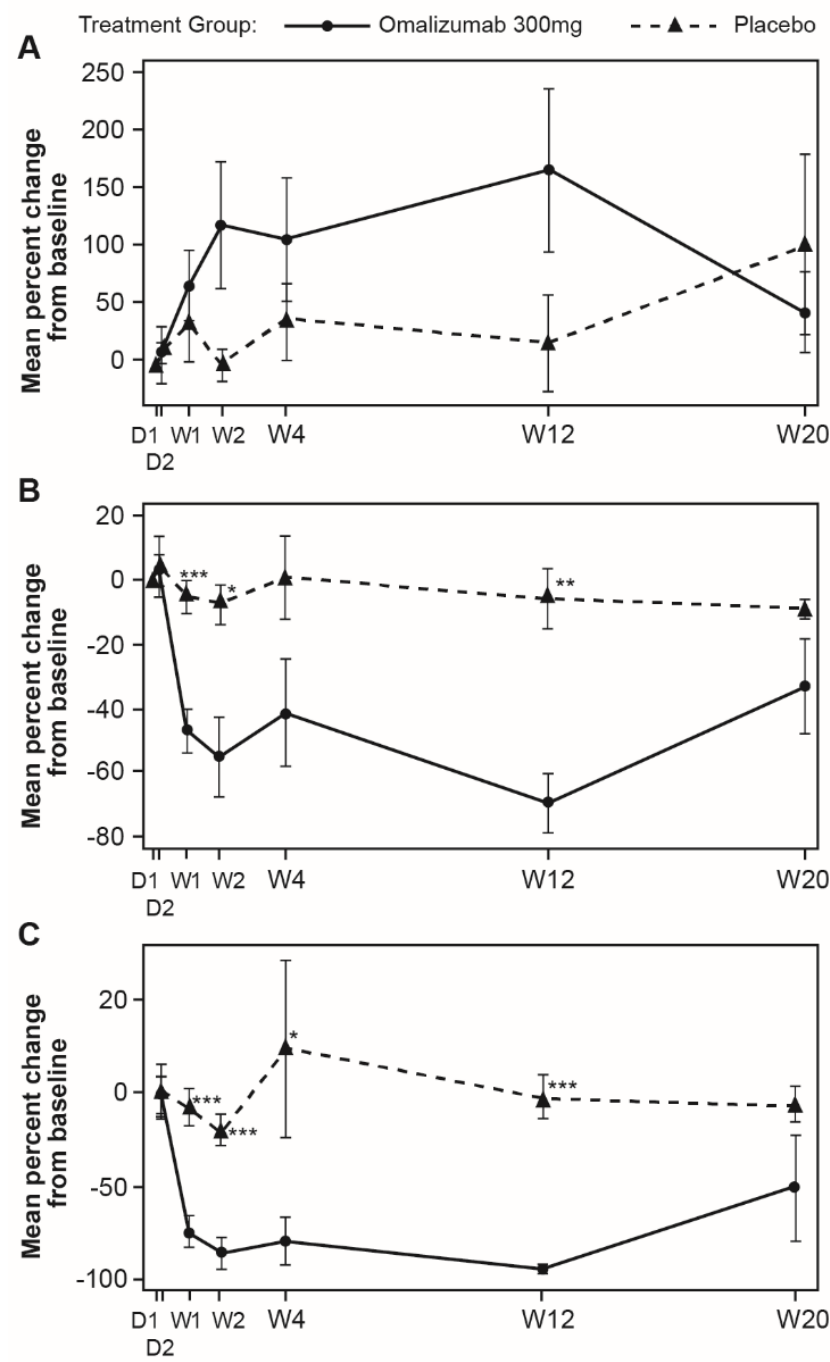

D, Day; W, Week

Figure 6 Changes in peripheral blood basophils during omalizumab treatment (mean, SEM). A: Peripheral blood basophils. B: FcERI expression. C: IgE expression. (* $\mathrm{p}<0.05$, ${ }^{*} \mathrm{p}<0.01$, and $* * * \mathrm{p}<0.001$; NS, not significant).). $\mathrm{D}$, day; $\mathrm{W}$, week

\section{Omalizumab treatment normalized levels of FceRI ${ }^{+}$and IgE+ skin cells}

Mean levels of FceRI and IgE expressing cells were higher in untreated CSU patients compared with HVs. Omalizumab, but not placebo, reduced these levels to those seen in HVs. In patients treated with omalizumab, mean levels of $\mathrm{FccRI}^{+}$cells were statistically significantly decreased at Week 12 compared with baseline (Day 1) in non-lesional skin (14.7 vs. 14.2 in HVs per visual field). Similar changes were observed for lesional skin (data not shown). No statistically significant changes in mean $\mathrm{FccRI}^{+}$cell levels occurred in the placebo group (Figure 7).

Similarly, mean levels of $\operatorname{IgE}^{+}$cells in the dermis of the omalizumab-treated patients were reduced to levels comparable with those of HVs at baseline. Decreases from baseline to Week 12 in mean levels of $\mathrm{IgE}^{+}$cells were observed in patients treated with omalizumab in dermis of non-lesional skin (9.80 vs. 8.76 in HV per visual field), (Figure 7). Little difference was observed for lesional skin (data not shown).

There was a good correlation of baseline UAS7 scores and FceRI-positive skin cells at baseline in lesional and non-lesional skin and the changes from baseline for these two parameters correlated for the non-lesional skin. No correlations were observed between UAS7 and IgE-positive skin cells at baseline but changes in UAS7 correlated with changes in IgE-positive skin cells after treatment in non-lesional skin as shown by Spearman correlation coefficient (Table 3).

Table 3. Correlation between UAS7 and FceRI-positive skin cells at baseline.

\begin{tabular}{|c|c|c|c|}
\hline Skin sample & $\mathrm{N}$ & $\begin{array}{l}\text { Pearson Correlation } \\
\text { (p-value) }\end{array}$ & $\begin{array}{l}\text { Spearman Correlation } \\
\text { (p-value) }\end{array}$ \\
\hline \multicolumn{4}{|c|}{$\begin{array}{l}\text { Correlation between UAS7 at baseline and FcERI-positive skin cells at } \\
\text { baseline. }\end{array}$} \\
\hline Lesional skin & 16 & $0.56(0.02)$ & $0.60(0.01)$ \\
\hline Non-lesional skin & 23 & $0.42(0.04)$ & $0.41(0.05)$ \\
\hline \multicolumn{4}{|c|}{$\begin{array}{l}\text { Correlation between change from baseline to Day } 85 \text { for UAS7 and change } \\
\text { from baseline to Day } 85 \text { in FceRI-positive skin cells }\end{array}$} \\
\hline Lesional skin & 16 & $0.33(0.2)$ & $0.24(0.4)$ \\
\hline Non-lesional skin & 23 & $0.44(0.04)$ & $0.38(0.07)$ \\
\hline \multicolumn{4}{|c|}{ Correlation between UAS7 at baseline and IgE-positive skin cells at baseline } \\
\hline Lesional skin & 16 & $0.33(0.2)$ & $0.22(0.4)$ \\
\hline Non-lesional skin & 23 & $0.39(0.07)$ & $0.32(0.1)$ \\
\hline \multicolumn{4}{|c|}{$\begin{array}{l}\text { Correlation between change from baseline to Day } 85 \text { for UAS7 and change } \\
\text { from baseline to Day } 85 \text { in IgE-positive skin cells }\end{array}$} \\
\hline Lesional skin & 16 & $0.19(0.5)$ & $0.15(0.6)$ \\
\hline Non-lesional skin & 23 & $0.38(0.08)$ & $0.45(0.03)$ \\
\hline
\end{tabular}




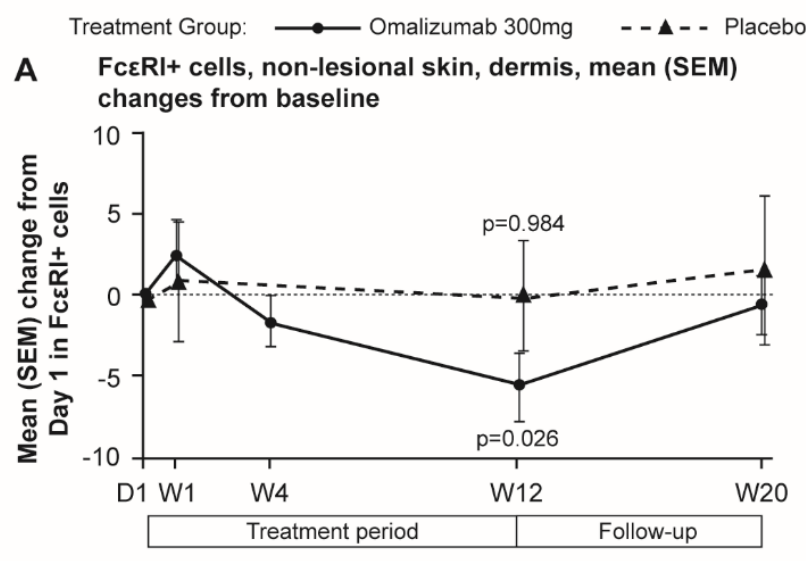

B IgE+ cells, non-lesional skin, dermis, mean (SEM) changes from baseline

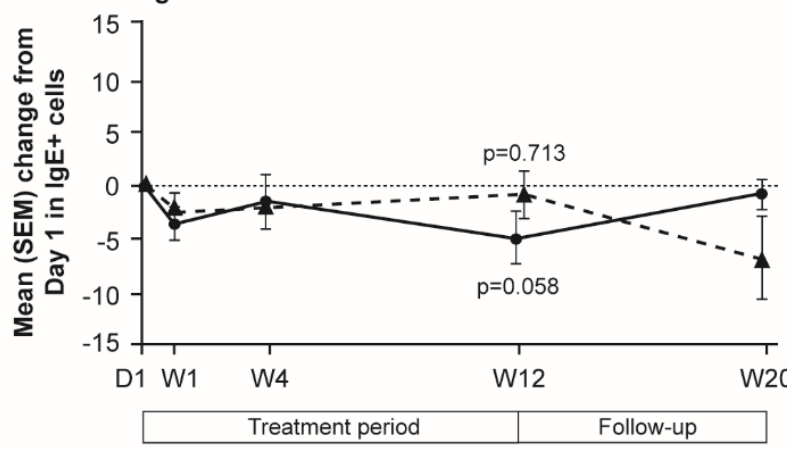

D, Day; W, Week

Figure 7. Mean (SEM) changes from baseline in $\mathrm{FcERI}^{+}$and $\mathrm{IgE}^{+}$cells per visual field in biopsy samples of dermis from CSU patients. A FcERI ${ }^{+}$cells, non-lesional skin. Baseline values, mean (SD): omalizumab 18.91 (9.42); placebo 20.48 (5.54). B lgE cells, non-lesional skin. Baseline values, mean (SD): omalizumab 13.82 (10.21); placebo 16.59 (9.35). D, day; W, week

\section{Omalizumab is well tolerated}

Omalizumab was generally well-tolerated in this study. The overall incidence of AEs was slightly higher in the omalizumab group than in the placebo group $(85 \%$ vs. $70 \%)$ and one person in the omalizumab group discontinued due to urticaria, which was considered mild and not considered to be related to study drug. The most frequently reported AEs overall was nasopharyngitis, which occurred at a similar rate in the omalizumab $300 \mathrm{mg}$ and placebo groups. Influenza and urticaria were the next most frequent AEs overall and were reported at the same frequency in each treatment group. The $\mathrm{AE}$ profile was not unexpected in the patient population being studied.

\section{Discussion}

Omalizumab has been shown to be effective in the treatment of CSU, but its mechanism of action is not fully understood. Omalizumab decreases circulating levels of free IgE in the bloodstream, but how this pharmacodynamic effect leads to the alleviation of the clinical signs and symptoms is not completely clear. In this study, treatment of CSU patients with omalizumab $300 \mathrm{mg}$ for 12 weeks was associated with reduced free IgE, consistent with the effect seen in asthma patients.[39] A statistically significant reduction in levels of $\mathrm{Fc}_{\mathrm{CRI}}{ }^{+}$cells in the dermis of non-lesional and lesional skin was observed and these results were temporally associated with the plateau of the improvement in clinical response. Reduction in FceRI ${ }^{+}$cells was also observed in a previous study of skin biopsies from patients with allergic rhinitis [4], and would be expected as FceRI ${ }^{+}$ cell density is dependent on free $\operatorname{IgE}$, which decreases during omalizumab treatment. $\operatorname{IgE}^{+}$cells in the dermis of non-lesional and lesional skin also decreased following omalizumab treatment although this decrease was not statistically significant. The decrease in $\mathrm{IgE}^{+}$cells was also expected, as omalizumab binds to free $\operatorname{IgE}$ and prevents it binding to FceRI. Subsequently, FccRI are down-regulated [5]. Levels of $\mathrm{FccRI}^{+}$and $\mathrm{IgE}^{+}$cells in omalizumab-treated patients at Week 12 had reduced to levels of those seen in healthy subjects at baseline. Overall, these results demonstrate that the systemic effects of omalizumab lead to local changes in the skin and there seems to be no difference in $\mathrm{FceRI}^{+}$and $\mathrm{IgE}$ levels between affected (lesional) and unaffected (non-lesional) skin.

While the mode of action of omalizumab in CSU patients is not fully understood, there are a few key hypotheses. One is that the density of IgE receptors at the surface of mast cells and basophils is proportional to the plasma-free IgE level [40]. Omalizumab binds to the same region on $\operatorname{IgE}$ as FceRI [41], reducing free IgE to near undetectable levels. This should therefore down-regulate the FceRI receptors so that e.g. potentially relevant IgG autoantibodies cannot cross-link FceRI [42]. Cell activation would be suppressed, as would all the subsequent inflammatory processes. As a consequence, the frequency and severity of symptoms of CSU should be markedly diminished. This would account for a therapeutic effect of omalizumab in the approximately $30 \%$ of CSU patients with such autoantibodies. However, in patients without detectable autoantibodies, IgE and FceRI seem to play an important role as well, as demonstrated by the efficacy of omalizumab in this population [43].

It has also been suggested that down-regulation of FceRI may be accompanied by an increase in the threshold above which degranulation of mast cells is triggered [44, 45]. This may be an independent mechanism of action, unrelated to prevention of cross-linkage of surface receptors. For degranulation to occur, a threshold number of receptors would need to be activated. The fall in free IgE after omalizumab 
treatment (both in the circulation and in tissue) and the reduction in the receptor density might therefore increase the threshold for degranulation to a much higher set point. Therefore, these two mechanisms may complement each other.

The efficacy of omalizumab in this study was similar to that observed in Phase III studies [9, 10]. Statistically significant and clinically meaningful reductions in UAS7 scores were observed over 12 weeks of treatment, with a mean decrease relative to placebo of -14.82 at Week 12. UAS7 decreased rapidly, with changes evident by one week after the first dose. Defining response to treatment as a $90 \%$ reduction in UAS7 from baseline, more than half of patients responded during the study, in line with that reported in key clinical studies of omalizumab [46]. Other clinical endpoints also showed improvements, including the physicians' and patients' global assessment scores, itch and hives assessment scores, percentage of angioedema-free days and use of rescue medication. Quality of life assessments (CU-Q2OL overall score, DLQI overall score and Skindex-29 score) also showed improvements. The observed correlations of FceRI-positive skin cells with UAS7 scores point to the relevance of these cells in CSU and further supports the observation that reducing these cells is linked to the mode of action and clinical efficacy of omalizumab.

Omalizumab decreases serum free IgE levels, and is associated with decreases in FceRI ${ }^{+}$cells and $\mathrm{IgE}^{+}$cells in lesional and non-lesional skin (dermis) of patients with CSU. These results support the hypothesis that one mode of action of omalizumab in CSU involves reduction of free $\operatorname{IgE}$, resulting in a down-regulation of surface $\operatorname{IgE}$ receptors, and subsequent reduction in downstream signaling via the FceRI pathway [42]. However, the clinical response to omalizumab defined e.g. by UAS7 change seems to occur much faster than the histological changes in the skin. Therefore, further mechanisms might be involved in the omalizumab mode of action. Interestingly, the reduction of FceRI and IgE positive peripheral basophils was much quicker and more closely reflected by the clinical response. This might be the result of an exchange of cells between different compartments (e.g. skin and blood). Importantly, changes in basophil parameters after omalizumab treatment were quick in onset like the decrease of free IgE but they were not indicative of clinical response as there was no correlation between basophil parameters and UAS7 (data not shown). Further investigations are required to determine the role and observed changes of peripheral basophils in CSU.

In conclusion, omalizumab was effective and well-tolerated in the treatment of CSU patients in this study, consistent with the results of earlier Phase II and III studies. While the results of this exploratory study do require verification and extension in a larger and appropriately powered investigation, the data suggest that the decrease in free IgE, resulting from omalizumab treatment, may lead to a reduction in $\mathrm{FceRI}^{+}$cells and $\mathrm{IgE}^{+}$cells in the dermis (to levels seen in healthy subjects). In addition, the changes observed in omalizumab-treated patients in peripheral blood basophils, in terms of basophil numbers, FceRI expression and responsiveness of basophils to activating stimulation by anti-IgE, may also be involved in the therapeutic effect of omalizumab. This is the first report demonstrating that the clinical effect of omalizumab correlates with histopathological markers.

\section{Acknowledgements}

Additional analyses of the data were performed by Fan Yang and Yaritza Ruiz (Novartis Pharma AG). The authors thank Southdown and Tina Patrick, Novartis Ireland Ltd. for providing medical writing and editorial support, which was supported by Novartis Pharma AG, Basel, Switzerland in accordance with Good Publication Practice (GPP3) guidelines (http:/ /www.ismpp.org/gpp3).

\section{Competing interests}

All authors have completed the Unified Competing Interest form at www.icmje.org/ coi_disclosure.pdf. Marcus Maurer and Martin Metz have received a research grant to their institution from Novartis; Marcus Maurer has been a paid consultant for Novartis and Genentech, received grants from Novartis, and been paid by Novartis for lectures and development of educational presentations; Andrea Bauer has been paid by Novartis for educational lectures and has been a member of the Novartis urticaria board; Randolf Brehler has received a research grant to the institution and has been paid for lectures and consultancy; Petra Staubach has been a paid consultant for Novartis: she has received travel support and received payment to her institution as the study centre, research grants, and payments for lectures and expert testimony; Janine Gericke is currently employed by Novartis Pharma $\mathrm{GmbH}$; her contribution to the work in this publication was performed while she was employed by Charité - Universitätsmedizin Berlin, where she received research grants from Novartis; Panayiotis Georgiou contributed to this work while employed at Novartis; he is now employed by Clovis Oncology, in which he holds stock options, and he also holds shares in Glaxo SmithKline; Rainer Hillenbrand, Joanna Ashton-Chess, Philip Jarvis, Veit Erpenbeck 
and Michael Kangas have received no support from any organisation for the submitted work, have had no financial relationships with any organisations that might have an interest in the submitted work in the previous 3 years and are employees of Novartis.

\section{References}

1. Omalizumab: anti-IgE monoclonal antibody E25, E25, humanised anti-IgE MAb, IGE 025, monoclonal antibody E25, Olizumab, Xolair, rhuMAb-E25. BioDrugs. 2002; 16: 380-6.

2. Hill DA, Siracusa MC, Ruymann KR, Tait Wojno ED, Artis D, Spergel JM. Omalizumab therapy is associated with reduced circulating basophil populations in asthmatic children. Allergy. 2014; 69: 674-7.

3. Lin H, Boesel KM, Griffith DT, Prussin C, Foster B, Romero FA, et al. Omalizumab rapidly decreases nasal allergic response and FceRI on basophils. J Allergy Clin Immunol. 2004; 113: 297-302.

4. Beck LA, Marcotte GV, MacGlashan D, Togias A, Saini S. Omalizumab-induced reductions in mast cell FceRI expression and function. J Allergy Clin Immunol. 2004; 114: 527-30.

5. Serrano-Candelas E, Martinez-Aranguren R, Valero A, Bartra J, Gastaminza G, Goikoetxea MJ, et al. Comparable actions of omalizumab on mast cells and basophils. Clin Exp Allergy. 2016; 46: 92-102.

6. Eggel A, Baravalle G, Hobi G, Kim B, Buschor P, Forrer P, et al. Accelerated dissociation of IgE-FcERI complexes by disruptive inhibitors actively desensitizes allergic effector cells. J Allergy Clin Immunol. 2014; 133: 1709-19.e8.

7. Saini S, Rosen KE, Hsieh HJ, Wong DA, Conner E, Kaplan A, et al. A randomized, placebo-controlled, dose-ranging study of single-dose omalizumab in patients with H1-antihistamine-refractory chronic idiopathic urticaria. J Allergy Clin Immunol. 2011; 128: 567-73.e1.

8. Maurer M, Altrichter S, Bieber T, Biedermann T, Brautigam M, Seyfried S, et al. Efficacy and safety of omalizumab in patients with chronic urticaria who exhibit IgE against thyroperoxidase. J Allergy Clin Immunol. 2011; 128: 202-9 e5.

9. Maurer M, Rosen K, Hsieh HJ, Saini S, Grattan C, Gimenez-Arnau A, et al. Omalizumab for the treatment of chronic idiopathic or spontaneous urticaria. N Engl J Med. 2013; 368: 924-35.

10. Kaplan A, Ledford D, Ashby M, Canvin J, Zazzali JL, Conner E, et al. Omalizumab in patients with symptomatic chronic idiopathic/spontaneous urticaria despite standard combination therapy. J Allergy Clin Immunol. 2013; 132: $101-9$

11. Saini SS, Bindslev-Jensen C, Maurer M, Grob JJ, Bulbul Baskan E, Bradley MS,et al. Efficacy and safety of omalizumab in patients with chronic idiopathic/spontaneous urticaria who remain symptomatic on $\mathrm{H} 1$ antihistamines: a randomized, placebo-controlled study. J Invest Dermatol. 2015; 135: 67-75

12. Staubach P, Metz M, Chapman-Rothe N, Sieder C, Brautigam M, Canvin J, et al. Effect of omalizumab on angioedema in $\mathrm{H}$-antihistamine resistant chronic spontaneous urticaria patients: results from $\mathrm{X}-\mathrm{ACT}$, a randomised controlled trial. Allergy. 2016; 71:1135-44.

13. Zhao ZT, Ji CM, Yu WJ, Meng L, Hawro T, Wei JF, et al. Omalizumab for the treatment of chronic spontaneous urticaria: A meta-analysis of randomized clinical trials. J Allergy Clin Immunol. 2016; 137(6):1742-1750.

14. Metz M, Ohanyan T, Church MK, Maurer M. Retreatment with omalizumab results in rapid remission in chronic spontaneous and inducible urticaria. JAMA Dermatol. 2014; 150: 288-90.

15. [Internet] European Medicines Agency. Omalizumab Summary of Product Characteristics. 2015. http://www.ema.europa.eu/docs/en GB/ document_library/EPAR_-_Product_Information/human/000606/WC50005 7298.pdf

16. [Internet] Genentech USA I. XOLAIR Prescribing Information. 2014. https://www.gene.com/download/pdf/xolair_prescribing.pdf

17. Zuberbier T, Aberer W, Asero R, Bindslev-Jensen C, Brzoza Z, Canonica GW, et al. The EAACI/GA(2) LEN/EDF/WAO Guideline for the definition, classification, diagnosis, and management of urticaria: the 2013 revision and update. Allergy. 2014; 69: 868-87.

18. Zuberbier T, Asero R, Bindslev-Jensen C, Walter Canonica G, Church MK, Gimenez-Arnau A, et al. EAACI/GA(2)LEN/EDF/WAO guideline: definition, classification and diagnosis of urticaria. Allergy. 2009; 64: 1417-26.

19. Elias J, Boss E, Kaplan AP. Studies of the cellular infiltrate of chronic idiopathic urticaria: prominence of T-lymphocytes, monocytes, and mast cells. J Allergy Clin Immunol. 1986; 78: 914-8.

20. Natbony SF, Phillips ME, Elias JM, Godfrey HP, Kaplan AP. Histologic studies of chronic idiopathic urticaria. J Allergy Clin Immunol. 1983; 71: 177-83.

21. Sabroe RA, Poon E, Orchard GE, Lane D, Francis DM, Barr RM, et al. Cutaneous inflammatory cell infiltrate in chronic idiopathic urticaria: comparison of patients with and without anti-FcERI or anti-IgE autoantibodies. J Allergy Clin Immunol. 1999; 103: 484-93.

22. Ying S, Kikuchi Y, Meng Q, Kay AB, Kaplan AP. TH1/TH2 cytokines and inflammatory cells in skin biopsy specimens from patients with chronic idiopathic urticaria: comparison with the allergen-induced late-phase cutaneous reaction. J Allergy Clin Immunol. 2002; 109: 694-700.

23. Grattan CE, Boon AP, Eady RA, Winkelmann RK. The pathology of the autologous serum skin test response in chronic urticaria resembles IgE-mediated late-phase reactions. Int Arch Allergy Appl Immunol. 1990; 93: 198-204.

24. Stone KD, Prussin C, Metcalfe DD. IgE, mast cells, basophils, and eosinophils. J Allergy Clin Immunol. 2010; 125: S73-80.

25. Konstantinou GN, Asero R, Ferrer M, Knol EF, Maurer M, Raap U, et al. EAACI taskforce position paper: evidence for autoimmune urticaria and proposal for defining diagnostic criteria. Allergy. 2013; 68: 27-36.

26. Hide M, Francis DM, Grattan CE, Hakimi J, Kochan JP, Greaves MW. Autoantibodies against the high-affinity $\mathrm{IgE}$ receptor as a cause of histamine release in chronic urticaria. N Engl J Med. 1993; 328: 1599-604.

27. Kaplan AP, Greaves M. Pathogenesis of chronic urticaria. Clin Exp Allergy. 2009; 39: 777-87.

28. Greaves M. Chronic urticaria. J Allergy Clin Immunol. 2000; 105: 664-72.

29. Metz M, Maurer M. Omalizumab in chronic urticaria. Curr Opin Allergy Clin Immunol. 2012; 12: 406-11.

30. Kikuchi Y, Kaplan AP. Mechanisms of autoimmune activation of basophils in chronic urticaria. J Allergy Clin Immunol. 2001; 107: 1056-62.

31. Sabroe RA, Greaves MW. Chronic idiopathic urticaria with functional autoantibodies: 12 years on. Br J Dermatol. 2006; 154: 813-9.

32. Vonakis BM, Saini SS. New concepts in chronic urticaria. Curr Opin Immunol. 2008; 20: 709-16.

33. Vonakis BM, Vasagar K, Gibbons SP, Jr., Gober L, Sterba PM, Chang H, et al. Basophil FceRI histamine release parallels expression of Src-homology 2-containing inositol phosphatases in chronic idiopathic urticaria. J Allergy Clin Immunol. 2007; 119: 441-8.

34. Eckman JA, Hamilton RG, Gober LM, Sterba PM, Saini SS. Basophil phenotypes in chronic idiopathic urticaria in relation to disease activity and autoantibodies. J Invest Dermatol. 2008; 128: 1956-63.

35. Djukanovic R, Wilson SJ, Kraft M, Jarjour NN, Steel M, Chung KF, et al. Effects of treatment with anti-immunoglobulin $\mathrm{E}$ antibody omalizumab on airway inflammation in allergic asthma. Am J Respir Crit Care Med. 2004; 170: 583-93.

36. Saavedra MC, Sur S. Down regulation of the high-affinity $\operatorname{IgE}$ receptor associated with successful treatment of chronic idiopathic urticaria with omalizumab. Clin Mol Allergy. 2011; 9: 2.

37. Mlynek A, Zalewska-Janowska A, Martus P, Staubach P, Zuberbier T, Maurer $\mathrm{M}$. How to assess disease activity in patients with chronic urticaria? Allergy. 2008; 63: 777-80.

38. Zielen S, Lieb A, De La Motte S, Wagner F, de Monchy J, Fuhr R, et al. Omalizumab protects against allergen- induced bronchoconstriction in allergic (immunoglobulin E-mediated) asthma. Int Arch Allergy Immunol. 2013; 160: $102-10$.

39. Milgrom H, Fick RB, Jr., Su JQ, Reimann JD, Bush RK, Watrous ML, et al.Treatment of allergic asthma with monoclonal anti-IgE antibody. rhuMAb-E25 Study Group. N Engl J Med. 1999; 341: 1966-73.

40. MacGlashan DW, Jr., Bochner BS, Adelman DC, Jardieu PM, Togias A, McKenzie-White J, et al. Down-regulation of FceRI expression on human basophils during in vivo treatment of atopic patients with anti-IgE antibody. J Immunol. 1997; 158: 1438-45.

41. Hochhaus G, Brookman L, Fox H, Johnson C, Matthews J, Ren S, et al. Pharmacodynamics of omalizumab: implications for optimised dosing strategies and clinical efficacy in the treatment of allergic asthma. Curr Med Res Opin. 2003; 19: 491-8.

42. Kaplan AP, Joseph K, Maykut RJ, Geba GP, Zeldin RK. Treatment of chronic autoimmune urticaria with omalizumab. J Allergy Clin Immunol. 2008; 122 : $569-73$

43. Zhao ZT, Ji CM, Yu WJ, Meng L, Hawro T, Wei JF, et al. Omalizumab for the treatment of chronic spontaneous urticaria: A meta-analysis of randomized clinical trials. J Allergy Clin Immunol. 2016; 137: 1742-50 e4.

44. Chang TW, Chen C, Lin CJ, Metz M, Church MK, Maurer M. The potential pharmacologic mechanisms of omalizumab in patients with chronic spontaneous urticaria. J Allergy Clin Immunol. 2015; 135: 337-42.

45. Asero R, Riboldi P, Tedeschi A, Cugno M, Meroni P. Chronic urticaria: a disease at a crossroad between autoimmunity and coagulation. Autoimmun Rev. 2007; 7: 71-6.

46. Kaplan A, Ferrer M, Bernstein JA, Antonova E, Trzaskoma B, Raimundo K, et al. Timing and duration of omalizumab response in patients with chronic idiopathic/spontaneous urticaria. J Allergy Clin Immunol. 2016; 137: 474-81. 